\title{
MAATALOUSMAAN ARVIOIMISESTA YHDYSVALLOISSA
}

\author{
P. H. KaARLehto \\ Helsingin yliopiston maatalouspoliittinen laitos
}

Saapunut 3. 1. 1954 .

Yhdysvalloissa ovat, kuten tunnettua, puhtaat liikeperiaatteet yleisesti vallitsevina myös maataloudessa. Tiloja ostetaan, myydään, annetaan ja otetaan vuokralle sikäli kuin kannattavuusnäkökohdat määräävät. Maatilan ostoa pidetään sijoituksena, josta odotetaan määrätyn suuruista korkotuloa, puhdasta tuottoa, eräiden tilan omistukseen liittyvien subjektiivisten arvotekijöiden lisäksi.

Näinollen tuntuukin luonnolliselta, että useimmat amerikkalaiset tutkijat, kuten Chambers (5), Wiecking (19), Gaddis (9), Doane (7), Stewart (16), Weawer (18) ja Murray (13) erikoisesti korostavat puhtaan tuoton merkitystä maan arvon määrittämisessä. Yleisesti tunnustetaan kuitenkin, että on olemassa tekijöitä, jotka aiheuttavat poikkeaman maatalousmaan markkinahinnan ja kapitalisoidun puhtaan tuoton välille. Vain aniharvat tiedemiehet Yhdysvalloissa, heistä huomattavimpina mainittakoon HAAS (10), BABCOCK (2) ja Rogers (15), ovat halunneet antaa markkinahinnoille sellaisenaan etusijan maatalousmaan arvioimisessa. Heidän perustelunsa tämän ns. kauppa-arviomenetelmän puolesta seuraavat hyvin tarkkaan AEREBoEn (1) jo v. 1912 esittämiä väitteitä.

Tällainen, pääasiassa tarkkojen arvojen määrittelyvaikeuksista johtuva tuottoarviomenetelmän hylkääminen on kuitenkin varsin vaikeasti puolustettavissa. Markkinahinnathan perustuvat joka tapauksessa tulevaisuuden puhtaan tuoton suuruuteen. Arvioinnin suorittaminen vain siirtyy markkinahintoihin turvauduttaessa erikoiskoulutetuilta ammattimiehiltä maan ostajien tehtäväksi. Lisäksi on muistettava, etteivät tilakauppoja koskevat tilastot suinkaan ole vailla virhelähteitä. Vaikeuksia tuottaa erikoisesti puhtaasti kaupallisten näkökohtienkin mukaisesti suoritetuissa myynneissä sellaisten seikkojen kuin maksuehtojen, maan laadun ja esim. erikoisen arvokkaiden kiinteistöjen tarkka selvittäminen. Jos taasen vedotaan kysyntä-tarjontatilanteen yksinomaiseen oikeutukseen hinnanmuodostuksessa, voidaan tähän huomauttaa, ettei erikoisesti maan kysyntää saisi käsittää muuttumattomana suureena. Jos viljelijöille selvitettäisiin kunkin tilan taloudellinen hinta, tuotto-arvo ja siitä johdettu pääoma-arvo, voidaan olla varmoja, että sillä olisi vaikutus keskimääräisiin kauppahintoihin. Tässä kohdin on muistettava niitä lukuisia erehdyksiä, joita maatilojen viljelytarkoituksiin ostajat ovat tehneet sopeutues- 
saan ilman tarpeellista kritiikkiä maatilojen markkinatilanteeseen, jossa erikoisesti Yhdysvalloissa spekulatiivisten tekijöiden vaikutus on varsin voimakas aiheuttaen lamakausina liian alhaiset ja nousukausina liian korkeat hinnat (13).

Kauppa-arviomenetelmän sovellutuksena on USA:ssa jonkin verran käytetty Rogersin (15) luomaa järjestelmää "The Comparative Method of Appraisal». Sen perustana ovat tietyn tilajoukon suhteellisen tarkasti eritellyt ja ryhmitellyt markkinahinnat. Kulloinkin arvioitavan maan kohdalta pyritään selvittämään määrättyjä tuottavuusarvoja, joiden perusteella se voidaan sijoittaa vastaavaan markkinahintaryhmään.

Vaikka kyettäisiinkin voittamaan tuottavuusryhmittelyyn liittyvät pulmat, lienee varsin suuria vaikeuksia edustavan kauppahintatilaston luomisessa ja ennen kaikkea sen pitämisessä ajan tasolla. Joka tapauksessa on huomattava, että menetelmä tarjoaa mahdollisuuksia lähinnä vain arvioimistieteen käytännölliseen soveltamiseen, ilman että se pyrkisi ratkaisemaan perusongelmia.

Maatalouden arvioimistieteen alalla ei siten Yhdysvalloissa ole alunperinkään esiintynyt niin voimakkaita mielipide-eroavaisuuksia kuin Euroopassa. Täysin yhtenäiselle linjalle päästiin siellä kuitenkin vasta v. 1934. Vuosikymmenen alun karvaat kokemukset virheellisen tilojen arvioimisen seurauksista ennen kaikkea luottoarvioinnin alalla saivat huomion kiintymään vakavasti käytännössä olevien menetelmien kehittämiseen ja yhtenäistämiseen. Tehtävää suorittamaan asetettiin v. 1933 komitea (Joint Committee on Rural Credits), missä olivat edustettuina luottolaitokset, maatalousyliopistot ja erilaiset maatalousjärjestöt. Tämä komitea ei päässyt kuitenkaan lopulliseen yksimielisyyteen käytettävän menetelmän yksityiskohdista, mutta sen alulle paneman työn täydensi »American Society of Farm Managers and Rural Appraisers»-niminen seura (6).

Amerikkalainen menetelmä "The American Rural Appraisal System» perustuu

siis olettamukseen, että maatalousmaata voidaan pitää sijoituksena ja että maatalous on yritysmuoto, jossa tehtyjen sijoitusten korkovaatimuksen tyydyttämiseksi saadaan riittävä tuotto. Näissä olosuhteissa on katsottu voitavan määrittää maan arvo seuraavissa vaiheissa (4).

1. Määritetään puhtaan tuoton arvo

2. Lasketaan puhtaan tuoton kapitalisoitu arvo

3. Arvioidaan ympäristötekijäin merkitys sekä suoritetaan vertailu kauppahintoihin.

Näistä saadaan ns. perusarvo, joka pohjautuu seudulle tyypillisellä talouden harjoittamisella saataviin tuloihin sekä keskimääräisiin ympäristö- ym. inhimillisenä tyydytyksenä ilmeneviin tekijöihin.

\section{Puhtaan tuoton määritiäminen}

Eräs USA:n liikeperiaatteellisesti tapahtuvan maataloustuotannon erikoispiirteitä on maatilojen vuokrauksen yleisyys. Näitä vuokratiloja tavataan kahta päätyyppiä, ensinnäkin sellaisia, joissa korvaus maanomistajalle suoritetaan osana 
sadosta (share rental) ja lisäksi sellaisia, joissa se maksetaan rahana (cash rental). Kun näinollen omistajan maasta saama tulo on verraten helposti numeroin ilmaistavissa, ovat maatalouden arvioimistieteen tutkijat USA:ssa saaneet aiheen käyttää vuokranmaksuja maan koko puhtaan tuoton kuvaajina varsinaisten puhdastuottolaskelmien sijasta.

Yksityiskohtaisen teoreettisen perustelun tälle menetelmälle on esittänyt Chambers (5). Hän osoittaa aluksi, että maatalousmaan kysyntä niiden taholta, jotka aikovat itse viljellä ostamaansa tilaa, on kyllin voimakas pitääkseen maan kauppahinnat kapitalisoitua puhdasta tuottoa vastaavina. CHAmbers sisällyttää tällöin tilan antamaan puhtaaseen tuottoon (farm rental) maasta perusparannuksineen ja asuntoetuudesta koituvan tulon. Tarkastellessaan sitten vuokran ja tilan antaman puhtaan tuoton suhdetta maan kysyntä-tarjontatilanteessa hän asettaa kysyntäpuolelle ne ostajat, jotka aikovat itse viljellä ostamaansa maata sekä vuokraajat. Tarjontapuolella ovat vuokralle antajat sekä myyntihaluiset.

Jos nyt vuokra laskee puhtaan tuoton alapuolelle, myyntihaluisten joukko suurenee ja vuokrattavien tilojen lukumäärä pienenee, sillä jos kapitalisoitu vuokra on alhaisempi kuin myyntihinta, kannattaa maanomistajan myydä tilansa ja kiinnittää rahansa esim. kuoletuslainoihin. Näin syntyy lisääntynyt kilpailu vuokrahaluisten kesken vuokratilojen tarjonnan supistuessa, josta taas seuraa vuokran kohoaminen puhdasta tuottoa vastaavaksi. Jos piintyneet vuokratavat pyrkisivät pitämään vuokraa puhtaan tuoton alapuolella, vaikuttaisi tämä kauppahintoja alentavasti, sillä jos vuokra olisi kapitalisoitua puhdasta tuottoa alempi vaikuttaisi lisääntynyt myyntitarjonta alentavasti kauppahintoihin. Tämä tilanne ei kuitenkaan voisi olla pysyvä, sillä lisääntynyt kilpailu vuokrahaluisten kesken nostaisi vuokran takaisin puhdasta tuottoa vastaavaksi ja siten vähenisi jälleen myyntihaluisten luku.

Jos taas maan arvo kysynnän vähenemisen johdosta laskee alle kapitalisoidun puhtaan tuoton, ei maan myynti ole kannattavaa, vaan maanomistajat antavat maata vuokralle enemmän kuin ennen, sillä vuokran kapitalisoitu arvo on tällöin korkeampi kuin myyntihinta. Täten kohoavat kauppahinnat tarjonnan heiketessä takaisin puhdasta tuottoa vastaavaksi.

CHAmbers päätyykin tutkimuksessaan siihen yleiseen lopputulokseen, että maanomistaja saa täyttä puhdasta tuottoa vastaavan vuokran, ja toisaalta muodostaa tämä vuokra kapitalisoituna perustan kauppahinnoille.

Edellä esitettyyn perusteluun voidaan tehdä eräitä muistutuksia. On erittäin tärkeätä huomata, ettei kysyntä vuokralle voi olla riippumaton tilojen ostoista, kuten Chambersin perustelu edellyttäisi. Vuokran laskiessa alle puhtaan tuoton ja entistä lukuisampien vuokralle antajien tarjotessa tilaansa kaupaksi, voidaan ajatella kauppahintojen laskevan niin, että osa vuokraajista lunastaa tilan itselleen, eikä näinollen synny edellytettyä lisääntynyttä kilpailua vuokrahaluisten kesken.

Tarkasteltaessa kysyntä-tarjontatilannetta graafisesti vastaa kuvio 1 CHAMBERsin esittämää tilannetta, kun taas kuviossa 2 on otettu huomioon, että osa tilojen ostajista saattaa olla entisiä vuokraajia. 


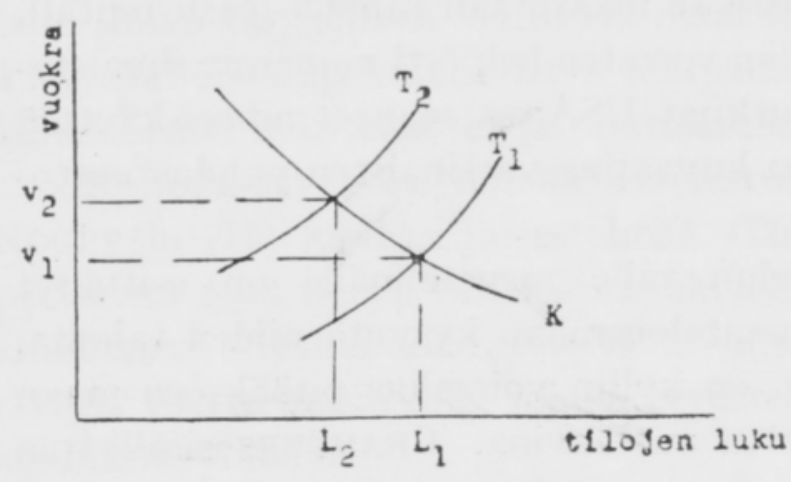

Kuvio 1

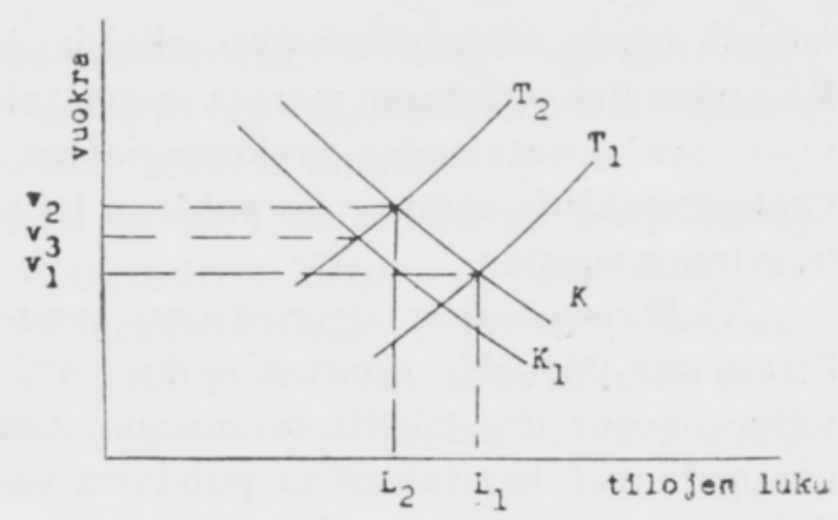

Kuvio 2
$\mathrm{T}_{1}=$ tarjonta vuokralle

$\mathrm{T}_{2}=$ myynnin takia vähentynyt tarjonta vuokralle

$\mathrm{K}=$ kysyntä vuokralle

$\mathrm{K}_{1}=$ ostojen takia vähentynyt kysyntä $\mathrm{v}_{1}=$ puhdasta tuottoa alhaisempi vuokra

$\mathrm{v}_{2}=$ puhdasta tuottoa vastaava vuokra

$\mathrm{v}_{\mathbf{3}}=$ uusi tasapainovuokra

$\mathrm{L}_{1}=$ vuokrattujen tilojen luku tarjonnan ollessa $\mathrm{T}_{1}$

$\mathrm{L}_{\mathrm{g}}=$ vuokrattujen tilojen luku tarjonnan ollessa $\mathrm{T}_{\mathrm{q}}$

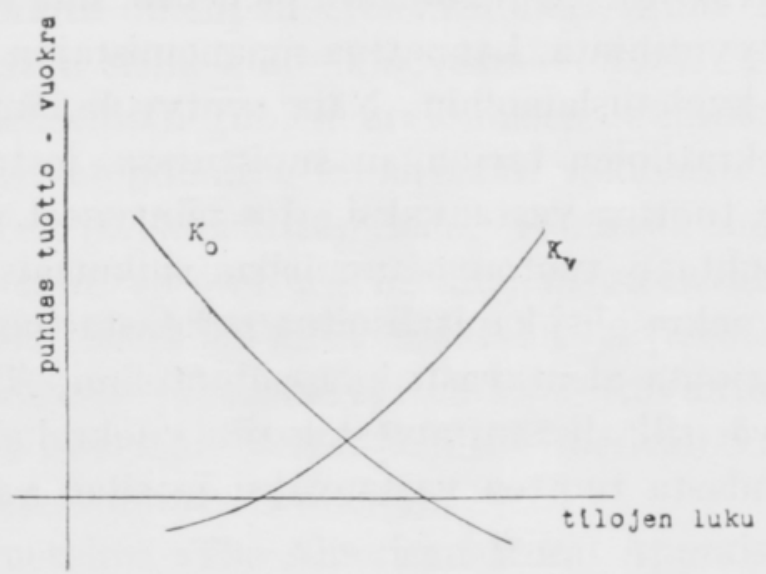

Kuvio 3

$\mathrm{K}_{0}=$ kysyntä ostoon $\quad \mathrm{K}_{v}=$ kysyntä vuokralle

Kuviosta 1 havaitaan, että kysynnän pysyessä muuttumattomana aiheuttaa tarjontakäyrän siirtyminen $T_{1}-T_{2}$ vuokrannousun $v_{1}-v_{2}$ ja laskun vuokrattujen tilojen luvussa $\mathrm{L}_{1}-\mathrm{L}_{2}$.

Kuviosta 2 selviää entisten vuokraajien tilanoston vaikutus vuokratasoon. Jos vuokrataso olisi jostain syystä, esim. kustannusten muutoksesta johtuen, laskenut alapuolelle puhtaan tuoton (kuviossa $\mathrm{v}_{1}$ :een), vähenisi tarjonta vuokralle (kuviossa $T_{1}-T_{2}$ ), niin että kysynnän pysyessä muuttumattomana vuokra kohoaisi puhdasta tuottoa vastaavaksi. Vuokralle tarjonnan väheneminen edellyttää kuitenkin, kuten edellä on todettu, myyntitarjonnan lisäystä. Ilman vastaavaa kysynnän kasvua joudutaan aluksi alentamaan kauppahintoja. Jos nyt vuokralle antajat pyrkivät koroittamaan vuokraa puhdasta tuottoa vastaavaksi, on luonnollinen seuraus, että osa entisistä vuokraajista lunastaa tilan itselleen. Näinollen ei kysyntää vuokralle voida pitää muuttumattomana suureena. Kuviossa on tätä kysynnän vähennystä ilmennetty kysyntäkäyrän siirtymisellä $\mathrm{K}-\mathrm{K}_{1}$. Helposti voidaan nyt 
todeta, että vaikka vuokra kohoaakin alentuneelta tasolta $v_{1}$. pysähtyy nousu tasolle $\mathrm{v}_{3}$, joka on alhaisempi kuin $\mathrm{v}_{2}$.

Kysymyksen ydin on siinä, kuinka monet vuokralaiset ovat halukkaita ostamaan tilan itselleen tai vaihtamaan ammattia vuokran lähestyessä puhdasta tuottoa. Vuokralainen sijoittaa maatalouteen sekä työtä että pääomaa yrittäjämielessä ja on siten sekä oikeutettu että halukas saamaan yrittäjävoittoa. Jos nyt vuokra määräytyy samaksi kuin puhdas tuotto tilalta on, ei hänellä ole mahdollisuutta sen hankkimiseen. Näin voi tapahtua ainoastaan sellaisilla markkinoilla, missä vuokralle antajilla on monopooliasema. Näin ei kuitenkaan ole laita Yhdysvalloissa.

Tasapaino kysynnän ja tarjonnan välillä muodostuukin siten, että vuokran laskiessa määrätyn määrän alle puhtaan tuoton, vuokraus käy edullisemmaksi kuin osto ja tilojen kysyntä vuokralle kasvaa pysäyttäen vuokran alenemisen. T a s apainovuokra $\left(=\mathrm{v}_{3}\right.$ kuviossa 2$)$ on siis käsitettävä tilojen oston ja vuokrauksen eri suuntiin käyvien etujen t a s a p in on a. Tätä tasapainotilannetta ilmennetään kuviossa 3 .

Edellisen lisäksi on huomattava eräitä käytännöllisiä seikkoja, jotka aiheuttavat eroja taloudellisen vuokran (economic rent) ja sopimusvuokran välillä. Taloudellisella vuokralla tarkoitetaan tällöin kaikkea maatilan tuottamaa tuloa ja sopimusvuokralla joko rahassa tai luonnontuotteissa suoritettua maksua. Kun vuokra tavallisesti määrätään pitemmäksi ajaksi eteenpäin, voi esim. hintasuhteissa tapahtua heilahduksia, jotka aikaansaavat muutoksia sopimusvuokran ja taloudellisen vuokran suhteessa. Tämä johtuu siitä, että hintatason noustessa tai laskiessa nopeasti ei tapahtuva muutos kustannus- ja tulotekijöissä yleensä ole samanlainen. Jos kustannukset esim. hintojen noustessa kohoavat hitaammin kuin tulotekijät, kasvaa taloudellisen vuokran ja sopimusvuokran välinen erotus vuokra-aikana, ts. vuokra suhteellisesti alenee, kunnes vuokrakauden päättyessä vuokraajalla on tilaisuus koettaa saada suhde entiselleen.

Kaikkein suurimmaksi muodostuu luonnollisesti taloudellisen vuokran ja sopimusvuokran keskinäinen vaihtelu yksinomaan rahavuokraa käytettäessä. Tällöinhän pääsevät sadon heilahtelut vaikuttamaan täydellä voimallaan, mitä ei tapahdu osavuokraa käytettäessä.

Jonkinlainen kuva siitä, missä määrin puhdas tuotto seuraa vuokraa, voidaan saada vertaamalla vuokraa pääviljalajin hinnoilla painotettuihin satoihin. Seuraavassa on esitetty nämä tiedot Iowan valtiosta viisivuotiskausittain $1930 \_45$

Keskimääräiset maissisadot Iowan valtiossa vuokratiloilla verrattuna nettovuokraan eekeriltä.

(U.S. Dept. of Agr. Econ.)

$\begin{array}{cccccc}\text { Vuosi } & \begin{array}{c}\text { Sato } \\ \text { bush }\end{array} & \begin{array}{c}\text { Hinta } \\ \text { doll bush. }\end{array} & \begin{array}{c}\text { Sadon arvo } \\ \text { dollaria }\end{array} & \begin{array}{c}\text { Puhdas vuokra } \\ \text { dollaria }\end{array} & \begin{array}{c}\text { Puhdas vuokra } \\ \text { \% sadon arvosta }\end{array} \\ 1930 & 34 & .60 & 20.40 & 5.57 & 27.3 \\ 1935 & 38 & .75 & 28.50 & 3.67 & 12.9 \\ 1940 & 52 & .67 & 34.84 & 4.24 & 12.6 \\ 1945 & 46 & 1.92 & 88.32 & 6.31 & 7.1\end{array}$


Joskin on pidettävä mielessä; että vuokran kapitalisoimisella pyritään nimenomaan keskimääräisen tuottoarvon määrittämiseen, osoittavat sarakkeessa 5 lasketut prosenttiluvut kuitenkin niin suurta vaihtelevaisuutta, että menetelmää on pidettävä epätarkkana. Kun puhtaan vuokran osuus sadon arvosta vaihtelee 27 $\%$ :sta $7 \%$ :iin, voidaan pitää todennäköisenä, etteivät vuokrat hintatason noustessa seuraa mukana, vaan jäävät jälkeen. Yleisestikin voitaneen näinollen katsoa, että kapitalisoitu vuokra-arvo jää alapuolelle todellisen tuottoarvon.

Pätevien puhtaan tuoton laskentamenetelmien ja sovellutusten puutteen vuoksi tarjoaa vuokran kapitalisointi kuitenkin nykyisellään ainoan mahdollisuuden tuottoarvon määrittämiseksi, huolimatta tähän selvästi liittyvästä systemaattisesta virheestä. Samasta puutteesta johtuen on mahdotonta tarkemmin numeerisesti määrittää yleisen vuokratason ja keskimääräisen puhtaan tuoton suhdetta.

Pyrittäessä käytännössä määrittämään tuottoarvoa vuokran perusteella, joudutaan varsin vaikean ratkaisun eteen silloin, kun on määriteltävä mitä hintoja käytetään maataloustuotteille. On luonnollista, ettei hintatasoksi voida arvostelutta valita nykyhetkellä vallitsevaa, sillä arvioinnissa käytettyjen hintojen tulee kuvastaa osaltaan tilan tulevaisuudessa antamaa tuottoa.

Oikean hintatason valinnan merkitystä korostaa BEAN (3) todeten, että maan hinnan vaihtelut ovat miltei täydellisesti selitettävissä maataloustuotteiden hintojen avulla. Suorittamiensa laskelmien perusteella hän esittää, että $52 \%$ maan hinnan muutoksista johtuu saman vuoden, $25 \%$ sitä edellisen vuoden sekä vastaavasti $8,6.5,3.1 \%$ aikaisempien vuosien hintasuhteista. Näinollen voitaisiin tilahintojen tuleva kehitys johtaa niistä odotuksista, joita viljelijöillä on seitsemän viimeksi kuluneen vuoden hintakehityksen perusteella.

Yleisemmässä muodossa esiintyy sama ajatus viimeksikuluneiden vuosien suuremmasta vaikutuksesta tulevaisuuden tilahintoihin menetelmässä, jossa maataloustuotteiden hintataso määritetään edellisten vuosien hintojen painotettuna liukuvana keskiarvona. Tätä menetelmää on tarkastellut MurRAY (13) suorittaen tavallisen liukuvan keskiarvon ja painotetun liukuvan keskiarvon menetelmillä laskettujen tulevaisuuden hintojen vertailun graafisessa taulussa. Tällöin osoittautuu punnittu keskiarvo seuraavan paremmin tilojen myyntihintoja kuin punnitsematon. Murray esittää kuitenkin eräitä tapauksia, joissa painotus voi johtaa väärään. Tällaisia ovat taloudellisissa oloissa tapahtuneet äkilliset heilahdukset tasapainoisesta kehityksestä, kuten liikatuotannon tai niukkuuden aikakaudet, riippumatta siitä, ovatko ne ulkonaisten vai sisäisten voimien synnyttämiä.

Amerikassa on paljon suosiota osakseen saanut tapa hintatason määräämiseksi monissa maataloudellisissa laskelmissa ns. normaalikausia käyttämällä. Perusvuosien 1. normaalivuosien valinnassa on tälläkin alalla päädytty kauteen 1909 1914, jolloin hintataso oli suunnilleen samalla korkeudella kuin vv. 1936 -40, hintaindeksien osoittaessa suhdetta 100:104.

Tässä kohdin on syytä panna merkille GADDIsin (9) lausunto, jossa hän esittää virallisen luottoarvioinnin perusteita hintatason määrittelyn kohdalta siten, että vv. 1910-14 hintatason voidaan odottaa kohtuudella pysyvän normaalisena keskimääränä siihen asti, kunnes "Agricultural Adjustment Act»in mukaiset lainat tuli- 
sivat takaisin maksetuiksi. Erikoisesti hän korostaa, että koska kysyntäolosuhteet eräiden tuotteiden kohdalta ovat huomattavasti muuttuneet, on tämä huomioitu vastaavasti niiden hintoja käsiteltäessä.

Normaalikausia käytettäessä on teoreettisessa mielessä virheellistä käyttää jotain aikaisempaa hintatasoa vertauskohtana. Maataloustuotteiden hinnat sinänsä eivät ole merkityksellisiä vaan niihin kytkeytynyt ostovoima. Erikoisesti pidempiä ajanjaksoja ajatellen ei tällä seikalla ole yksinomaan teoreettinen, vaan myös huomattava käytännöllinen merkitys.

BOWEN ja MAYER (4), selostaessaan varsinaisen amerikkalaisen maatalouden arvioimismenetelmän käytäntöä tuotteiden hintoja määrättäessä, esittävät kolme tekijää, nim. aika, paikka ja tuotteen laatu, jotka aiheuttavat vaihtelua hinnoissa.

Ajan merkitys on siinä, että kaikkien tuottoarvon määrittämisessä käytettyjen hintojen tulee edustaa tulevaisuuden keskimääräistä hintatasoa. Etsittäessä aikaisempien tilastojen avulla edustavaa hintatasoa, suositellaan painotettujen lukuarvojen käyttöä. Niistä erilaisista tekijöistä, jotka vaikuttavat hintakehitykseen, on huomioitava erikoisesti yleiset taloudelliset olosuhteet, hallituksen maatalouspolitiikka, kasvinjalostuksen kehitys, sää- ja tuotantojaksot, tuotantomäärät, markkinoimisolosuhteet ja ko. tuotteen erikoisominaisuudet.

Paikallisten hintaerojen selvittämiseksi on valmistettava erikoisia hintakarttoja, ja näissä olevat arvot on tarkistettava vuosittain. Yksityisissä tapauksissa voi arvioitsija korjata näitä hintoja mikäli perusteltua syytä ilmenee. Aihetta muutoksiin saattaa olla

a) farmeilla, joilla myynti on suoritettava epäedulliseen aikaan varastojen puutteen vuoksi,

b) farmeilla, joiden sijainti joko läheisyytensä tai kaukaisuutensa tähden antaa aihetta muutokseen.

c) paikallisista häiriöistä johtuvat muutokset.

Lopuksi on hintoihin tehtävä muutoksia milloin tuotteen laatu oleellisesti poikkeaa hinta-alueen tyypillisestä laatutasosta.

Lähdeaineistona amerikkalaisessa menetelmässä käytetään tuotteiden tilahintoja sellaisina kuin ne ovat saatavilla virallisista satotilastoista. Vuosittaisia keskihintoja voidaan käyttää kunhan ne painotetaan markkinoitujen tuotteiden määrillä.

Tuotteiden hintatason määrittely lienee tuottoarviomenetelmän vaikeimpia osatehtäviä. Amerikassa saatavilla olevat suhteellisen laajat tilastot ovat omiaan helpottamaan arviointia tällä kohdalla. Tärkeätä olisi kuitenkin korostaa ostovoimaarvon käytön merkitystä suoranaisten hintavertailujen sijasta, kuten edellä jo on esitetty. Tilastoista saadun perusaineiston soveltamisessa on arvioitsijalla käytettävissään kuitenkin vain melko ylimalkaiset ohjeet, joten lopputulos jää osittain riippuvaiseksi subjektiivisista tekijöistä. Tulosten vertailukelpoisuuden lisäämiseksi olisi näinollen tärkeätä pyrkiä ohjeiden täsmennykseen.

Tarkasteltaessa edellä periaatteellisesti mahdollisuuksia selvittää maan arvo kapitalisoimalla maasta maksettu vuokra, on koko ajan tarkoitettu nettovuokraa, ts. vuokraa, josta maanomistajalle lankeava osa tuotantokustannuksia on vähen- 
netty pois. Tällaisia kustannuksia ovat verot, vakuutukset, pääomien poistot ja korot sekä suoranaiset erät, jotka riippuvat kustakin yksityisestä sopimuksesta. Suoranaisia eriä saattavat olla esim. siemenkustannus sekä arvioitu korvauserä liikeyrityksen johtotyöstä.

Vuokralle antajan kustannuksista on erikoista huomiota kiinnitettävä pääomakustannuksiin ja tällöin nimenomaan rakennuskustannuksiin. Amerikàssa on ollut käytännössä kaksi menettelytapaa näiden määrittämiseksi, ns. vakinaisten sijoitusten menetelmä (constant building investment) sekä uutisarvo-arvonalennus menetelmä (cost new, less deppriciation). Edellisessä on periaatteena, että arvioidaan keskimääräinen vuosittainen summa, jonka avulla rakennukset jatkuvasti voidaan pitää nykyisessä kunnossaan. Kun näinollen rakennusten voidaan katsoa tulevaisuudessakin tyydyttävän asunto-, varasto- ym. tilan tarpeet, on mahdollista käsitellä rakennuksia ja maata yhtenä kokonaisuutena.

Arvostellessaan vakinaisten sijoitusten menetelmää MurRAY (13) huomauttaa kuitenkin, ettei se ole käytännöllinen mikäli rakennukset ovat aivan uusia tai hyvin vanhoja. Olisi nimittäin varsin epämukavaa laskea keskimääräisiä kustannuseriä, jotka tosiasiallisesti lankeavat maksettavaksi vasta monien vuosien perästä, kuten olisi tehtävä uusien rakennusten kohdalla. Vanhojen rakennusten suuret kustannuserät puolestaan aiheuttaisivat helposti kohtuuttomia virheitä kokonaislaskelmissa.

Edellä mainituissa rajatapauksissa suosittelee MurRAY käytettäväksi uutisarvo-arvonalennus menetelmää. Tämän menetelmän mukaan lasketaan tilan tulot ja menot ikäänkuin rakennukset olisivat uudet, sekä vähennetään lopuksi kapitalisoidusta nettovuokratulosta rakennusten uudisarvon ja nykyarvon välinen erotus.

Molempien menetelmien avulla voidaan arvioitaessa päästä täysin samaan tulokseen, jos vain osataan arvioida oikein ero uudelle ja vanhalle rakennukselle asetettavissa vuotuisissa kustannuksissa.

Seuraten eurooppalaisten arvioimistieteen tutkijain yleistä linjaa, korostaa MurRAy samassa yhteydessä sitä, ettei maatilan arvioinnissa ole käsitettävä rakennuksen rakennuskustannuksia ja sen arvoa samaksi. Minkään rakennuksen arvo ei voi kohota yli sen summan, jolla kyetään hankkimaan uusi ko. tarpeen tyydyttävä rakennus. Tästä joudutaankin helposti käyttöarvon mukaiseen arvioimiseen.

Käyttöarvo voitaisiin määrittää arvioimalla se menetys, mikä aiheutuisi rakennuksen tuhoutumisesta. Tämän tappion suuruus voitaisiin selvittää esim. vuokranmaksujen alenemisen perusteella, tai vähemmän tyydyttävinä asunto-oloina. Erittäin hankalaksi käy kuitenkin maatilan arvioiminen, jos kiinteistöt on jaettu maaksi ja rakennuksiksi, sillä rakennusten arvioinnissa liikutaan aina varsin epävarmalla pohjalla.

Arvosteltaessa MurRayn edellä esitettyä menetelmää vuotuisten maanomistajalle koituvien rakennuskustannusten arvioimisesta, on huomio kiinnitettävä eräisiin tässä esiintyviin vaikeuksiin. Erikoista taitoa arvioitsijalta vaatii korjauskustannusten vuotuiserän ja suoritettujen poistojen oikean suhteen löytäminen. Jos poisto on alhainen, täytyy vuosittaisiin korjauksiin käyttää suhteellisen paljon varoja rakennuksen kestoiän jatkamiseksi. Kuoletuserien laskemiseksi erilaisille raken- 
nuksille olisi näinollen varsin tärkeä selvittää kunkin rakennustyypin keskimääräinen kestoaika, kun edellytetään kunnossapitokustannukset vakioksi.

Omat vaikeutensa on myös sellaisen maatalousmaan arvioimisessa, jolla ei ole minkäänlaisia rakennuksia. Tässä tapauksessa vaikuttaa maasta saadun vuokratulon suuruuteen lähiseudun yleinen rakennustilanne. Murray (13) eroittaakin kolme mahdollisuutta: 1) Tilanne, jolloin naapureilla on käyttämätöntä rakennuskapasiteettia. Esimerkkinä tällaisesta tilanteesta on "Corn-Belt» vyöhyke, missä tekniikan kehitys on aiheuttanut pyrkimyksen suurempiin tilakokoihin. Täällä saattavat viljelijät maksaa paljaasta maasta lähes yhtä suurta vuokraa kuin rakennetustakin. 2) Tilanne, jolloin paikkakunnalla ei ole ylimääräistä rakennustilaa, mutta ei myöskään puutetta siitä. Tässä tapauksessa muodostuu vuokra huomattavasti alhaisemmaksi kuin edellisessä. 3) Tilanne, jolloin esiintyy yleistä puutetta rakennustilọista. Tällöin saattaa olla melko vaikeata löytää vuokralaisia lainkaan. Vuokra alenee, mutta ei kuitenkaan paljoa enempää kuin rakennuskustannuksia vastaavasti, sillä tällöinhän kannattaisi ostaa maa ja rakentaa se.

Huomattavan vuokratuloista vähennettävän erän muodostavat myös rakennusten palovakuutukset. Koko USA:lle laskettu keskimääräinen vakuutusmaksu on vaihdellut 1930 -luvulla $2.30-3.20 \%$ vuodessa (17). Kun tämä vakuutusmaksu on saatu laskemalla yhteen kaikkien keskinäisten yhtiöiden korvaussummat ja yleiskustannukset kutakin 1000 dollarin vakuutussummaa kohden, on luonnollista, että eri valtioissa esiintyy tässä kohdin huomattavia vaihteluita. "Vakuutusmaksutaulujen ja arvioidun jälleenrakennusarvon avulla on tämä kustannuserä verraten tarkasti määritettävissä kullakin seudulla. Kustannuslaskelmissa olisikin vakuutusmaksut aina perustettava jälleenrakennusarvoon, vaikka maksu tosiasiallisesti suoritettaisiinkin alemmasta summasta. Tilan omistajan on palon sattuessa joka tapauksessa hankittava tuottoarvon muuttumattomana pitämiseksi tuhoutuneen tilalle sen tehtävät täyttävä rakennus. Näinollen kuvastaa jälleenrakennusarvon mukaan laskettu vakuutusmaksu hänen kannettavanaan olevaa riskiä.

Vuokralle antajan maksettavia veroja arvioitaessa liikutaan myös selvällä tilastollisella pohjalla. Siitä huolimatta ei tämän kustannuserän määritys ole ilman tiettyjä vaikeuksia. Tulevaisuuden verorasituksen arvioiminen tapahtuu amerikkalaisen maatalouden arvioimismenetelmän mukaan kahdessa täysin erillisessä osassa (4). Toisaalta määritellään yleisen maatilaverotuksen kehityssuunta, toisaalta odotettavissa oleva erikoisverotus. MurRay (12) teroittaa, että tulevaisuuden veroja arvioitaessa on huomattava paitsi aikaisempaa verorasitusta, myös odotettavissa olevat kuntien lisämenot, esim. suurten rakennussuunnitelmien toteuttaminen yms.

Lopuksi on huomattava koko joukko mahdollisesti kysymykseen tulevia erikoiskustannuseriä, jotka, riippuen paikallisista tavoista, saattavat tulla maanomistajan maksettaviksi. Tällaisina erinä voivat esiintyä mm. menot siemeniin, lannoitteihin ja kalkkiin. Näiden luovutusten hinnoittelu tapahtuu samoin perustein kuin mitä yleisen hintatason määrittelyssä on käytetty. 


\section{Puhtaan tuoton kapitalisoiminen}

Yksinkertaisimmin voitaisiin kapitalisointi tietysti suorittaa olettamalla puhdas tuotto ikuiseksi, jolloin tuottoarvokaava saa seuraavan muodon

$$
\begin{aligned}
& \mathrm{v}=\frac{\mathrm{a}}{\mathrm{r}} \text {, kun } \\
& \mathrm{v}=\text { kapitalisoitu arvo } \\
& \mathrm{a}=\text { vuotuinen puhdas tuotto } \\
& \mathrm{r}=\text { korkosadannes }
\end{aligned}
$$

Tämän yleisen kapitalisoimiskaavan mukaista laskelmaa puolustavat ELY ja WeHRwerN (8) osoittamalla, että kun tuoton edellytetään jatkuvan samanlaisena, tasoittuvat maataloudessa runsaina esiintyvät epävarmuustekijät.

CHAmbers (5) esittää kapitalisoidun arvon määrittämiseksi kaavan

$$
\begin{aligned}
& \mathrm{v}=\frac{\mathrm{a}}{\mathrm{r}}+\frac{\mathrm{i}}{\mathrm{r}^{2}} \\
& \mathrm{v}=\text { kapitalisoitu arvo } \\
& \mathrm{a}=\text { vuotuinen puhdas tuotto } \\
& \mathrm{r}=\text { korkosadannes } \\
& \mathrm{i}=\text { vuotuisen puhdastuoton odotettu lisäys }
\end{aligned}
$$

Tässä oletetaan voitavan arvioida tulevaisuudessa tapahtuva puhtaan tuoton lisäys, tai jos kaava kirjoitetaan muotoon

$$
v=\frac{a}{r} \pm \frac{i}{r^{2}}
$$

myös mahdollinen vähennys, joten siis osa maan arvosta perustetaan tulevaisuuden odotuksiin.

Arvosteltaessa edellä esitettyjä laskutapoja on todettava, että vaikkakin maatalousmaan tuottava voima on verraten pysyvää on arveluttavaa pitää sitä ikuisena. Varsinkin Amerikan oloissa, missä eroosionvaara on suhteellisen suuri, lienee paikallaan ottaa kapitalisoitaessa mukaan myös aikatekijä. Jos esimerkiksi korkokanta olisi $5 \%$, niin 20 ensimmäisen vuoden kuluessa saataisiin vain noin $62 \%$ rajattoman ajan kaavan mukaan lasketusta tulosta. Aikarajoituksen oikeutukseen viittaa sekin seikka, ettei voida missään tapauksessa ajatella hintatason määrittelyä rajattomaksi ajaksi.

Tulevaisuuden tuotonlisäyksen huomioiva empiirisesti johdettu kaava on mitä suurimmassa määrin epävarmuustekijöitä sisältävä. Se on johdettu pitemmältä ajanjaksolta kerättyjen tilahintojen ja vuokrien keskinäisestä riippuvaisuussuhteesta. Kaavan merkitystä voitaisiin tulkita myös siten, että tietyn kauppahinnan omaavasta tilasta tulevaisuudessa maksetaan pienempi vuokra kuin nykyhetkellä, ts. vuokran suhde kauppahintaan pienenee. Se seikka, että kyseinen kaava on pystynyt selittämään tuoton ja kauppahintojen keskinäisen riippuvaisuussuhteen määrätyn ajanjakson kuluessa ei suinkaan sinänsä oikeuta tehtyyn johtopäätökseen, 
että kauppahinnat osittain olisivat riippuvaisia tulevaisuudessa odotettavissa olevasta tuoton lisäyksestä tai vähennyksestä. Aikasarjoja käytettäessä tutkimuksen perustana, on aina otettava huomioon rakennemuutoksien mahdollisuus tutkittavassa populaatiossa. Niinpä tässäkin tapauksessa on mahdollista, että esim. maatalouden koneellistaminen on syynä muutokseen vuokran ja kauppahinnan suhteessa.

Viimeisten 30 vuoden kuluessa on vuokralaisen tilanhoidossa tarvitsemien pääomien määrä jatkuvasti kasvanut yhdessä maatalouden koneellistumisen ja koko elinkeinon kaupallistumisen kanssa. Jos nyt ajatellaan vuokratilalta saatavan puhtaan tuoton jakautuvan vuokran ja vuokralaisen osuuteen yrittäjävoitosta siihen tapaan kuin edellä olevassa luvussa esitetään, o n t o d e n n ä k ö is t ä, e t tä jälkimmäinen osuus kasva sitä mukaa kuin vuokralaisen pääomakustannus lisääntyy. Täten on täysin mahdollista, että esitetyn katran sopivaisuus määrätlle ajanjaksolle merkitsee aivan mu uta kuin sitä suhdetta, joka tulevaisuudessa odotettavalla tuoton lisäyksellä on ka p pahintoihin.

Tavallisen rajattoman ajan korkokaavan ohella esittää MurRAY (13) myös toisen yleisen yhtälön, joka perustuu tulevaisuuden tulojen nykyarvon määräämiseen. Tämä kaava edustaa yksinkertaisinta menetelmää aikatekijän huomioonottamisesta siten, että kunakin vuonna tulevaisuudessa saatavien tulojen nykyarvot lasketaan yhteen. Tämä yleisesti tunnettu kaava on

$$
\text { nykyarvo }=\frac{1}{(1+=\text { korkokanta })^{n}} \cdot \text { tulevaisuuden tulo, }
$$

jossa n osoittaa vuosien lukua nykyhetken ja tulon saamishetken välillä.

Tätä kaavaa voidaan käyttää hyväksi myös silloin, kun puhdas tuotto on nouseva tai laskeva. Jos tuotto esim. olisi 600 , 700, 800, 900 ja 1000 dollaria viiden ensimmäisen vuoden aikana ja 1000 dollaria jatkuvasti sen jälkeen, saadaan tuottoarvo kapitalisoimalla 1000 dollarin tuotto rajattoman ajan kaavaa käyttäen (5\% mukaan se tekee 20000 dollaria) ja vähentämällä tästä 400, 300, 200 ja 100 dollarin nykyarvot vastaavat vuosimäärät huomioiden (yhteensä 908 dollaria), jolloin tuottoarvoksi tulisi 19092 dollaria. Tämä menetelmä on varsin suositeltava tiloilla, joilla suoritetaan pitkäaikaisia perusparannuksia useamman vuoden kuluessa.

Jos tilan tuottoarvoa vähentää tuulen tai veden aiheuttama eroosio, taikka jos on odotettavissa verojen tai tuotantokustannusten kohoaminen, tulee kysymykseen tuottoarvio laskevan puhdastuoton perusteella. Jos esim. arvioidaan saatavan 500 dollaria kahtena vuotena, 400 dollaria kahtena seuraavana ja 300 dollaria jatkuvasti sen jälkeen tulee tuottoarvoksi $5 \%$ mukaan $6000+541$ dollaria.

BABCOCK (2) johtaa kaavan rajoitettuna aikana saadun tuoton kapitalisoimiseksi seuraavaan tapaan. Jos vuosittainen tulo on 1.00 ja korko $5 \%$ on ensimmäisen tuloerän arvo $1 / 1.05$, toisella $1 / 1.05^{2}$, kolmannella $1 / 1.05^{3}$ jne. Yleistettynä siten, että korkoa merkitään i:llä saisi kaava muodon 


$$
\begin{aligned}
& \mathrm{a}_{3}=(1+\mathrm{i})^{-1}+(1+\mathrm{i})^{-2}+(1+\mathrm{i})^{-3}, \text { tai jos on kysymyksessä n vuotta } \\
& \mathrm{a}_{n}=(1+\mathrm{i})^{-1}+(1+\mathrm{i})^{-2}+\ldots(1+\mathrm{i})^{-(n-1)}+(1+\mathrm{i})^{-n}, \text { eli } \\
& \mathrm{a}_{n}=\frac{1-(1+\mathrm{i})^{n}}{\mathrm{i}}, \text { ja jos vuotuista tuloa merkitään R:llä } \\
& \mathrm{R}_{a n}=\mathrm{R}\left(\frac{1-(1+\mathrm{i})^{-n}}{\mathrm{i}}\right)
\end{aligned}
$$

On huomattava, että edellä esitetyt yhtälöt suurelta osalta seuraavat yleisesti käytännössä olevia kapitalisoimiskaavoja. Ainoana itsenäisenä Yhdysvalloille ominaisena parannusyrityksenä tuottoarvon laskemisessa on pidettävä pyrkimystä selittää tilojen kauppahintojen muodostuminen tuoton ja tulevaisuuden tuotonlisäysodotusten funktiona.

Paljon vaikeampi kuin matemaattisiin menettelytapoihin perustuva laskukaavan määrittely, on sovellettavan oikean korkokannan löytäminen. Niinpä kuuluisan saksalaisen arvioimistieteen tutkijan AEREBoEn (1) mielestä on juuri oikean korkokannan määrittelyn vaikeus ratkaiseva este tuottoarviomenetelmän käytön tiellä.

Luonnollisin lähtökohta oikean korkokannan löytämiseksi on vertailu sellaisiin tunnettuihin sijoitustapoihin, joissa sijoittajalla on mahdollisimman samanlainen riski kannettavanaan kuin on maatalousmaan omistajalla. Tällöin tulee lähinnä kysymykseen kuoletuslainojen korko. Eräät tutkijat, kuten REGAN, Johnson ja CLARENBACH (14), ovat sitä mieltä, että kuoletuslainojen keskimääräinen korko olisi liian alhainen käytettäväksi kapitalisoimisessa, koska lainapääoman likviditeetti on suurempi. Sitäpaitsi voidaan väittää, että tilan omistukseen kytkeytyy suurempi riski kuin vastaavalla lainoituksella hankittuun tuloon, ja että kapitalisoinnissa on aina käytettävä korkeampaa korkokantaa, jotta viljelijä kykenisi suoriutumaan veloistaan.

Tämän väitteen johdosta esittää MurRay (13), että näin olisikin laita, ellei tila olisi yhtä hyvin koti kuin liikeyritys. "This home value is one factor, which tends to bring the rate down from a purely business rate to one, approximately the first mortgage interest rate».

Tämä, perustelun ensimmäinen osa, voidaan kuitenkin todeta epäjohdonmukaiseksi sikäli, ettei varsinaisen tuottoarvon määrittämisessä tulisi ottaa huomioon muita kuin rahatulona arvioitavia tekijöitä. Tilan koti-arvon, samoinkuin ympäristötekijäinkin arvon määrittäminen, on täysin erillisenä suoritettava tehtävä, joka tapahtuu lähinnä vertailtaessa tuottoarvoa kauppahintoihin. Olisi varsin ratkaiseva virhe, jos tämä huomioitaisiin kapitalisoimiskokoa määritettäessä, sillä näin menetettäisiin mahdollisuus suorittaa arvio siitä, miten paljon ostaja joutuu maksamaan tilan suomasta epätaloudellisesta tarpeentyydytyksestä.

Toisena tekijänä, joka puhuu kuoletuslainojen koron käyttämisen puolesta, MURRAY esittää tämän korkokannan ja maan kysynnän ja tarjonnan keskinäisen riippuvaisuussuhteen. Hänen päättelynsä tapahtuu seuraavasti. Maan omistus olisi edullisempaa kuin kiinnityslainojen antaminen siihen, jos kapitalisoimiskorko olisi paljon korkeampi kuin kuoletuslainakorko. (Tähän voidaan heti huomauttaa, ettei tuotto yksinään määrää sijoituksen edullisuutta, vaan myös tuoton varmuus.) 
Tästä seuraisi lisääntynyt tilojen ostohalu ja toisaalta vähentynyt halu lainojen antamiseen, mikä aiheuttaisi korkokannassa nousua ja kapitalisoimiskorossa laskua. Päinvastainen tilanne olisi yhtä pysymätön.

Murrayn todistelu, joka seuraa CHAMbERsin (5) esitystä, on täysin pätemätön: Todistuksen olettamuksenahan on ilmeisesti seikka, joka pitäisi osoittaa oikeaksi. Jos maanomistukseen liittyisi suurempi riski kuin kiinnityslainojen hallintaan, ei maanomistus olisi edullisempaa kuin kiinnityslainojen antaminen, vaikka kapitalisoimiskorko olisikin korkeampi kuin kuoletuslainakorko. Ainoa päätelmä, joka todistelusta voidaan tehdä, on, että oikean kapitalisoimiskoron ja kuoletuslainakoron erotuksen tulee osoittaa riskin eroavaisuutta kummassakin yritysmuodossa. Todellisuudessa lieneekin niin, että erikoisesti rahalaitosten kautta kulkevat kuoletuslainasijoitukset ovat jonkin verran varmempia kuin sijoitukset yksityisiin farmeihin.

Murray toteaa lopuksi, että joskin kapitalisoimiskoron ja kuoletuslainakoron välillä on määrättyjä riippuvaisuustekijöitä, jotka pyrkivät kaventamaan korkokantojen välistä eroa, saattaa esiintyä myös muita tekijöitä, joiden vaikutus on näitä voimakkaampi. Tällaisia tekijöitä ovat odotettu hintakehitys sekä maanviljelijän haluttomuus tilansa myymiseen, koska hänellä ei ole muuta ammattia. Toisaalta ei luottolaitos lopeta lainaustaan, vaikka lainakorko putoaisikin alle kapitalisoimiskoron.

Amerikkalaisen maatalouden arvioimismenetelmän mukaan (4) esitetään, että korkokanta olisi määriteltävä tulevaisuutta silmällä pitäen seuraten kunkin alueen erikoisominaisuuksia fysikaalisissa, taloudellisissa ja sosiaalisissa suhteissa. Tämän korkokannan tulisi mahdollisesti olla lähellä käypää kuoletuslainojen korkoa saman alueen vastaavanlaisilla tiloilla. Korkokantaan vaikuttavista tekijöistä mainitaan erikoisesti:

1) Rahamarkkinat, yleiset ja alueelliset,

2) Riski, fysikaalinen ja taloudellinen,

3) Kiinteistöjen likviditeetti,

4) Kilpailu muiden sijoitusmuotojen kanssa.

Vaikean kysymyksen eteen joutuu maan arvioitsija myös silloin, kun kuoletuslainan korko muuttuu. Vv. 1920-46 vaihteli keskimääräinen kuoletuslainakorko USA:ssa 6.3 ja 4.5 \% välillä. Tämän vaihtelun merkitys selvenee, kun ajatellaan, että jälkimmäistä korkokantaa käyttäen saatu kapitalisoitu arvo on n. $45 \%$ suurempi kuin edellistä käytettäessä. Murray (13) korostaa, että kunkin muutoksen jälkeen olisi odotettava jonkin aikaa ja tarkkailtava korkokannan pysyväisyyttä. Joskaan ei ole mitään varmoja perusteita uuden korkokannan käytäntöönottoajan määrittelemiseksi, on kuitenkin hyödyllistä suorittaa vertailuja kauppahintojen vaihteluihin, josta käy selville ostavan ja myyvän yleisön käsitys muutoksen pysyväisyydestä.

Paikallisten vaihteluiden selvittämiseksi on USA:ssa valmistettu erikoisia korkokarttoja. Voidaan todeta, että paikalliset erot ovat suurempia kuin edellä esitetyt vuosittaiset vaihtelut, niin että esim. Texasin valtiossa saatetaan käyttää samanaikaisesti $5 \%$ ja $8 \%$ korkokantoja.

Kyetäksemme arvostelemaan, missä määrin nämä vaihtelut on yleistettävä 
koskemaan myös kapitalisoimiskorkoja, on paras selvittää kyseisten erilaisuuksien syntymisen syyt. Murray (13) esittää tässä kohdin kaksi pääsyytä. Tärkein on riskin vaihtelevaisuus. Riski, joka vähentää luoton antajan halua lainoitukseen, vaikuttaa vastaavasti tilan ostajaan. On luonnollista, että tällaiset erot otetaan huomioon korkokantaa määriteltäessä. Eräänä syynä korkeaan lainakorkoon saattaa olla myös suuri etäisyys rahalaitoksista. Tämäkin tekijä olisi huomioitava kapitalisoitaessa, koska tilan myyjällä on samat vaikeudet koettaessaan hankkia ostajaa, kuin viljelijällä yrittäessään saada käsiinsä lainan antajaa. Lisäksi on otettava huomioon ostajan vaihtoehtoiset mahdollisuudet käyttää pääomansa verraten korkeakorkoiseen lainaukseen.

Myös lainojen keskimääräinen koko saattaa vaikuttaa korkokantaan. Pienten lainojen korkokustannukset muodostuvat verraten suuriksi, mikä puolestaan edellyttää korkeaa korkoa. Tällaisten vaihtelujen perusteella kapitalisoimiskorkoa muutettaessa lienee syytä olla varsin varovainen.

Lopuksi on paikallaan todeta, että vaikka Yhdysvaltain maatalousministeriön alaisten luottolaitosten toiminta vaikuttaa korkovaihteluita tasoittavasti, ei kaikilla kuitenkaan ole tilaisuutta ja halua hankkia tarvitsemiaan lainoja niistä, joten erilaisuudet korkokannoissa ovat jossain määrin pysyviä.

\section{Ympäristötekijäin mittaaminen ja vertailu kauppahintoihin}

Tarkasteltaessa sijainnin vaikutusta maan arvoon, voidaan eroittaa toisaalta ne tekijät, joiden vaikutus ilmenee taloudellisena tuottona ja toisaalta ne, joiden vaikutus ilmenee sosiaalisina etuina.

Amerikkalaisessa maatalouden arvioimismenetelmässä otetaan ympäristötekijät huomioon tehtäessä korjauksia tuottoarvolaskelmaan. Kun menetelmän periaatteiden mukaisesti tuottoarvio suoritetaan keskimääräisiä olosuhteita vastaten, muodostavat korjaukset sen sillan, joka johtaa yksityisen tilan arvon määrittelyyn. Bowen ja MaYer (4) luokittelevat korjaustekijät seuraavaan tapaan.

A. Sijainti ja taloudelliseen käyttöön vaikuttavat tekijät, jotka ilmenevät rahallisena etuna

1. Markkinapaikka, tiet ja kuljetusmahdollisuudet

2. Kunta

3. Yleinen käyttökelpoisuus ja vertailu naapuristoon

4. Tappionvaara

5. Asuntoetuus

6. Perusparannukset

7. Fysikaaliset tekijät

8. Sivuansiomahdollisuudet

9. Luontaiset voimavarat

10. Muut tekijät

B. Sosiaaliset ja koti-tekijät, jotka ilmenevät inhimillisenä tyydytyksenä omaisuuden käytöstä

1. Talon ja pihan ominaisuudet

2. Virkistys- ja näköalatekijät

3. Kirkko- ja koulusuhteet

4. Naapuruussuhteet

5. Muut tekijät 
Erikoisesti kehoitetaan huolellisuuteen ja tarkkaavaisuuteen, jotta taloudellisten tekijäin vaikutusta määritettäessä vältyttäisiin huomioimasta seikkoja, jotka jo ilmenevät puhtaassa tuotossa.

Tarkasteltaessa edellä esitettyä menetelmää ympäristötekijäin huomioonottamisesta, on pantava merkille luettelossa esiintyvien taloudellisten tekijäin mukaan otto. Tuntuu vaikealta käsittää miksei perusparannusten ja fysikaalisten tekijäin vaikutus ilmenisi jo bruttotuotossa. Etäisyys markkinapaikasta vaikuttaisi tavallisessa puhdastuottolaskelmassa luovutushintojen vaihtelevaisuutena, ja keskimääräisiäkin luovutushintoja käytettäessä amerikkalaisen menetelmän mukaisesti, tulisi korjaus suorittaa jo hintatasoa määriteltäessä eikä loppuarvoon. Tappionvaaran vaihteluista taasen suurin osa ilmenee korkokannassa, tai pitäisi korjaukset suorittaa siihen eikä loppuarvoon.

MURRAY (13) korostaa erikoisesti sitä, ettei sijainti-olosuhteita voida pitää pysyvinä. Uusien teiden tai koulujen rakentaminen ja kuljetusneuvojen kehitys muuttavat jatkuvasti tilojen arvoa tässä suhteessa. Sijaintitekijäin ilmaisemista rahana vaikuttaa puolestaan, ettei voida kuvitella mitään ihanteellista esimerkkiä, koska inhimilliset toivomukset ovat varsin erilaisia.

Taloudellisesti tärkeimpinä sijaintitekijöinä voidaan pitää etäisyyttä markkinapaikasta ja tien laatua. Näitten merkitystä on USA:ssa pyritty selvittämään kuljetuskustannuksia analysoimalla.

Erikoisesti Kellog ja Ableiter (ref. Murray 13) ovat tutkineet tilan arvon riippuvaisuutta etäisyydestä markkinapaikkaan. Tässä tutkimuksessa on ensin määritelty keskimääräinen vehnäsato alueen paraslaatuisimmalla maalla, sekä 40 eekerin tilan vehnäntuotanto edellyttäen $52 \%$ maasta vehnänviljelykseen. Siitä on vähennetty siemenen ja rehuksikäytön osuus ja täten laskettu markkinoitavaksi jäänyt sadonosa. Kuljetus markkinoille on ajateltu tapahtuvaksi autolla keskimäärin neljänä lastina. Vehnäsadon markkinointi tulisi tällöin maksamaan .64 dollaria mailia kohden tai kapitalisoituna $5 \%$ mukaan 12.80 dollaria. Tämä luku on sitten kerrottava etäisyydellä maileissa lausuttuna ja lopuksi vähennettävä parhaassa asemassa olevan tilan arvosta, jotta tuottoarvot tulisivat oikeaan suhteeseen.

Valitettavasti laskelma koskee ainoastaan tuotteiden myyntiä. Täydellisemmän kuvan saamiseksi olisi suoritettava vastaava laskelma myös tarvikkeiden, ennen kaikkea lannotteiden kohdalta, sekä selvitettävä millainen vaikutus etäisyydellä on työpalkkoihin.

Amerikassa on myös valmistettu arvioitsijoita varten erikoisia lomakkeita käytettäväksi miellyttävyystekijäin selvittämisessä, joista esitetään malli seuraavassa $(13)$.

I Sijainti

Etäisyys kaupungista, 2 mailia

Tien laatu, kestopäällystetty

Sähkö, ei

Posti ja puhelin, on

Erikoiset tappionvaarat, ei $\wedge$ Arvoaste

A B C D E 
II Kunta

Kansallisuudet, sekoittuneet

Vuokraus, 30 1/2

Kouluolot, hyvät

Kirkot, useita

Ansiomahdollisuudet, -

Huvittelumahdollisuudet, hyvät

III Kotiolosuhteet

Talon sijainti, kohtalainen

Piha, heikko

Rakennustyyli, kohtalainen

Näköala, ei

Tuulenmurtaja, ei

IV Rakennukset, yli keskitason

Asuinrakennus, ei

Vajoja, ei

Muita rakennuksia, ei

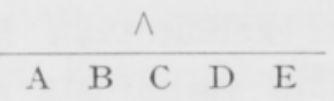

\begin{tabular}{lllll}
\multicolumn{1}{c}{$\wedge$} \\
\hline & B & C & D & E
\end{tabular}

\begin{tabular}{ccccc}
\multicolumn{1}{c}{} & \multicolumn{1}{c}{$\wedge$} \\
\hline A & B & C & D & E
\end{tabular}

Jos edellä esitettyjen tekijäin merkitystä haluttaisiin tarkemmin määritellä, voitaisiin painot MurRaYn mukaan asettaa seuraavasti: Sijainti 50, Kunta 20, Kotiolosuhteet 20 ja Rakennukset yli keskitason 10.

Amerikkalaiselle arvioimistieteen tutkimukselle on tyypillistä kahden eri arvioimismenetelmän yhteensovittamispyrkimys. Ennakkoluulottomasti on siellä suhtauduttu tuottoarviomenetelmän puutteellisuuksiin, eikä suinkaan vaikeuksien edessä sitä hyljätty, vaan on kaikin keinoin yritetty puutteita korjata. Tutkimuksissa on havaittu tuoton ja kauppa-arvon välillä vallitseva selvä riippuvaisuussuhde. Kauppa-arvo kuvastaa ostajien ja myyjien käsitystä siitä, millaisiksi muodostuvat lainojen korkoprosentti ja maataloustavaroiden hinnat, kun taas tuottoarvon perustana on arvioitsijan käsitys hintakehityksestä ja kapitalisoimiskorosta.

Kuten jo edellä on todettu, ylittävät keskimääräiset tilojen kauppahinnat vastaavasti lasketut tuottoarvot. Tämä ero johtuu normaalioloissa suurelta osalta siitä, että ns. miellyttävyystekijät jäävät tuottoarvossa huomioimatta. Näiden tekijöiden raha-arvon määrittäminen on mahdollista suorittamalla vertailuja kauppahintoihin. Siten esim. Hudelson (11) korostaa, että ainoa objektiivinen tapa miellyttävyystekijäin arvioimiseksi on tutkia kauppahintatilastoa ja siten selvittää kuinka paljon tyypillinen ostaja on halukas maksamaan tietyn tuottoarvon omaavasta tilasta miellyttävyystekijöille osoitettua lisähintaa.

Pyrkimyksenä onkin ollut saada aikaan tilaston pohjalta erikoinen miellyttävyystekijöiden luokitus, jossa kunkin luokan raha-arvo määritetään tuotto- ja kauppa-arvon välisen eron perusteella. Siten esim. miellyttävyysarvoltaan erinomaisen A-luokan tilan tuottoarvo saattaisi olla vain puolet kokonaisarvosta.

Tällaista luokkiin perustuvaa vertailua on pidettävä varsin onnistuneena. Vertailu kauppahintoihin antaa arvioitsijalle erinomaisen tilaisuuden pitää arviointinsa oikeassa suhteessa keskenään, mutta vain sillä edellytyksellä, että hän pystyy 
määrittämään kuinka suuri osuus kauppa-arvosta on luettava miellyttävyystekijäin tiliin.

Lopuksi on todettava, että kauppa-arvon perusteella suoritetut korjaukset ovat luonnollisesti riippuvaisia siitä, mitä tarkoitusta varten arviointi suoritetaan. Siten esim. tervettä, lainan ottajan etuja katsovaa luottopolitiikkaa noudatettaessa luottoarvioinnissa on huomio ennen kaikkea kiinnitettävä tuottoon, kun sensijaan osto- ja myyntiarviointeja suoritettaessa on kummankin arvo-osan merkitys selvitettävä yhtä tarkasti.

\section{KIR JALLISUUTTA}

(1) Aereboe, Friedrich 1912. Die Taxation von Landgütern und Grundstücken. 542 p. 52 Tafeln. Berlin.

(2) BABcock, Frederick 1932. The Valuation of Real Estate. 593 p. New York - Lond.

(3) Beax, Louis H. 1938. Inflation and the Price of Land. Journal of Farm Economics, XX, p. 310320. Menasha.

(4) Bowen, John, and Mayer, Lester B. 1946. The American Rural Appraisal System. Journal of the American Society of Farm Managers and Rural Appraisers, Oct. 1946, p. 84 -99. Storm Lake.

(5) Chambers, Clyde R. 1924. Relation of Land Income to Land Value. U.S. Dept. of Agriculture, Dept. Bull. 1224, 132 p. Washington.

(6) Doane, Howard D. 1934. Report of the Committee on Rural Appraising of the National Joint Committee on Rural Credits. Journal of Farm Economics, XVI, p. 291-292. Menasha.

(7) $\rightarrow$ 1937. Appraisal Theory and Practice. Ibid., XIX, p. 161-168. Menasha.

(8) Ely, Richard T., and Wehrwein, George S. 1948. Land Economics. 512 p. New York.

(9) Gaddis, P. L. 1937. The Appraisal of Farm Lands. Journal of Farm Economics, XIX, p. 401415. Menasha.

(10) HaAs, G. C. 1922. Sale Price as a Basis of Farm Land Appraisal. Minn. Agr. Experiment Station, Tech. Bull., 9, p. 3-4. Minnesota.

(11) Hudelson, Robert R. 1945. The American System of Farm Appraisal in Theory and Practice. Journal of the American Society of Farm Managers and Rural Appraisers, Appr. 1945, p. 44 -48. Storm Lake.

(12) Murray, William G. 1949. Agricultural Finance. 372 p. Ames.

(13) - 1950. Farm Appraisal. 278 p. Ames.

(14) Regan, M. M., Johnson, A. R., and Clarenbach, Fred A. 1945. - The Farm Real Estate Situation 1943-44. US. Dept. of Agr. Cir., 721. 46 p. Washington.

(15) Rogers, C. N. 1946. The Comparative Method of Appraisal. Journal of the American Society of Farm Managers and Rural Appraisers, Oct. 1946, p. 117-122. Storm lake.

(16) Stewart, Clyde E. 1947. The Concept of Normal Value in Farm Land Appraisal. Ibid., Oct. 1947, p. 117-118. Storm Lake.

(17) Valgren, V. N. 1938. Problems and Trends in Farmers Mutual Fire Insurance. US. Dept. of Agr. Bull., 23, p. 23. Washington.

(18) Weawer, Howarns S. 1950. School of Real Estate, Farm Land Appraising with Essentials of Farm Management and Engineering, 407 p. 19. Kansas City.

(19) Wieckivg, E. H. 1933. An Evaluation of the Present Economic Position of Agriculture by Regions and in General. Farm Real Estate Values. Journal of Farm Economics, XV, p. 260-269. Menasha. 
S U M M A R Y :

\title{
ON THE AMERICAN SYSTEM OF RURAL APPRAISING
}

\author{
P. H. KaARLEHTO
}

University of Helsinki, Department of Agricultural Policy

The author gives a critical report on the American system of rural appraising. Although the advantages of the system, in which income appraisal and commercial appraisal are effected parallelly, are realized, there seem to be some considerations in need of further study.

The author devotes special attention to the possibility of using net rent as a measure of land value. Since the appraisal method is to a great extent based on capitalization of net landlord income or net rent, the question arises whether the average net rent equals the average annual net return from the farms. The author concludes that this cannot be the true situation in the USA. It is inevitable that the tenant invests his labour and capital as entrepreneur and is therefore quite justified in demanding a part of the entrepreunial rent. If, however, net rent equals net return he does not get any of it. This can happen only in cases where land is scarce and landowners maintain monopoly power.

A real equilibrium is possible only when the advantages of purchasing and of renting are in balance from the viewpoint of the farmer.

Even a rapid survey of recent trends in the composition of farm capital shows how greatly increased is the share of farm investment which to-day must be met by the tenant. Again, it has been statistically shown that the difference between capitalized rent value of land and its market value has been increasing during the last few decades. In all probability a part of this difference may be the result of an increase in the share of the farm capital which the tenant has to invest, and thus perhaps has no relation to the increase or decrease of net return from the farm.

Among other minor points raised by the author, the problem of determining the right capitalization rate seems to him to be especially in need of further intensive study. 